standard for tannic acid ointment. Five appendixes to the Addendum revise existing directions for as many processes ; they relate to the determination of (1) ultra-violet absorption, (2) iodine value, (3) unsaponifiable matter in fixed oils and fats, (4) alde. hydes or volatile oils, and (5) the assay of vitamin A.

\section{Biological Films}

The Gaumont British Instructional Films Bureau has recently added some interesting biological films to its already extensive collection. "Climbing Plants" portrays clearly the many different devices for climbing adopted by plants in their struggle for existence, including 'scramblers', thorn, petiole and aerial root climbers, as well as types that climb by means of tendrils and stems. The photographs of circumnutation in the bean seedling are as excellent as the rest of the film. In "The Swan", the photographer has captured some entertaining 'shots' of the famous swannery at Abbotsbury, near Weymouth. Courtship and breeding are carefully presented, as well as pleasant recordings of cygnet development. "The Life-Story of a Fern" includes photographs of royal, hart's-tongue, male and bracken ferns, indicating methods of spore production and liberation. In this film some informative pictures of fertilization processes in the ferns are particularly noteworthy.

"The Emperor Moth" describes the complete lifecycle of the insect from the egg to the emergence from the pupal case. The value of this film, as of many other insect films, is that the activities and development of the insect over a period of weeks may be seen as a coherent picture within a few minutes. In "Marshland Birds" various island builders like the dabchick, great crested grebe, the coot, swan and moorhen are seen in various stages of their life-history, as also are shore-builders such as the snipe, wild duck, bittern, yellow wagtail, bearded tit, reed warbler and heron. Photographs of predators like the short-eared owl and the harrier are included in order to introduce an ecological concept. In this film the photographer has secured many pictures which must be ranked well outside the usual. The appearance of these five films bears witness to the continued technical progress that is being made in the production of biological films.

\section{Observation of Chimpanzees}

AN experimental laboratory for the observation of behavioural development and adjustment, growth and maturation of chimpanzees has recently been established at the Yale Laboratories of Primate Biology, Orange Park, Florida. Infants are to be separated from their mothers at birth and reared under controlled conditions as subjects of a special research by Dr. Henry W. Nissen, assistant director. Up to March 1940, Prof. R. M. Yerkes records (Science, 91 ; April 5, 1940), 34 infants have been born in the colony, which contains 27 individuals of known birth-date and recorded life-history out of a total population of 47, ranging in age from four days to twenty-seven years. Several of these chimpanzees have resided in the colony for 8-14 years. Though the normal life of this great ape in captivity has not been determined, it is indicated that the reproductive life may exceed thirty years, while probably in favourable conditions the individual may live for fifty years. The average interval between generations in the breeding colony is almost exactly nine years.

With regard to the special problems of behaviour, it may be noted that of two primiparous mothers, neither accepted nor cared for their infants at birth. Each behaved as if surprised and bewildered, while lacking suitable, ready-to-hand patterns of behaviour for the novel emergency. Nor did either consume the afterbirth. By contrast, multiparous mothers usually eat at least part of the afterbirth and almost invariably treat the new-born infant as a familiar object, handling it skilfully and ensuring its welfare. The structurally determined maternal behaviour of the primiparous chimpanzee is importantly supplemented by acquisitions resulting from individual reproductive experience and also by social tradition.

\section{Control of Weeds and Grassland Experimentation}

The Imperial Bureau of Pastures and Forage Crops, Aberystwyth, has recently published three new bulletins. No. 27, "The Control of Weeds" (7s. 6d.), is a symposium dealing with the various aspects of the problem as it occurs in different parts of the world, particularly in the British Commonwealth and the United States. Increasing attention is being paid to this question; extensive research work on cultural, chemical and biological means of control is in progress, and important results are already available. The practices characteristic of each country make interesting comparison. The outlook regarding chemical measures of control, for example, is very different in the United States and Germany, stress being laid on the value of cultural methods in the latter case. In Australia and New Zealand biological means have been used, with spectacular success in the eradication of prickly pear in Australia. Poisonous weeds are the subject of an article from South Africa, while Canada's contribution is chiefly ecological.

Bulletin No. 28 (2s. 6d.) describes the "Technique of Grassland Experimentation in Scandinavia and Finland". This includes both the technique for the quantitative measurement of grass production and that of stock-grazing trials. The methods of grassland analysis are chiefly contributed from Denmark and Sweden, while the grazing experiments described were carried out in Norway and Finland. Bulletin No. 29 (5s.) is entitled "Grassland Investigations in Australia". This publication may be regarded as a continuation of Bulletin No. 14 issued in 1934, which dealt with a similar subject. The enormous variation in climate naturally raises very diverse problems in the different parts of the country, but in general the pasture investigations cover two main features, natural pasture maintenance and regeneration, and the treatment of sown pastures, together with the problems of the winter and summer rainfall zones. 